\title{
Sovereign Immunity, the Officer Suit Fiction, and Entitlement Benefits
}

\author{
John F. Duffy†
}

The constitutional doctrine of sovereign immunity prohibits a federal court from entertaining any suits in which a sovereign entity, either a state or the United States, ${ }^{1}$ is named as defendant unless the sovereign has consented to be sued. Despite the absolute terms in which sovereign immunity is sometimes described, ${ }^{2}$ there exist two fundamental limitations on its sweeping prohibition. First, the legislature of the relevant ${ }^{3}$ sovereign (as opposed to the sovereign itself) may tender the necessary consent through an ordinary legislative act. Second, relying on an ancient fiction, known as an "officer suit" or an "official capacity suit," courts may entertain suits against officers of the sovereign and grant relief that effectively runs against the government. ${ }^{*}$ Since a government can act

† A.B. 1985, Harvard University; J.D. Candidate 1989, University of Chicago.

1 Though the federal courts sometimes treat the doctrines of state and federal sovereign immunity differently, the precedents for each doctrine continue to be cited in cases involving the other. Justice Frankfurter, for example, believed that "[t]he sources of the immunity are formally different but they present the same legal issues." Larson v Domestic \& Foreign Commerce Corporation, 337 US 682, 708 (1949) (Frankfurter dissenting). See also Pennhurst State School \& Hosp. $v$ Halderman, 465 US 89, 112-116 (1984) (heavily relying upon the reasoning of Larson, a federal sovereign immunity case, in deciding a state sovereign immunity case.) This comment generally accepts current Supreme Court precedent holding that state sovereign immunity is as broad as federal sovereign immunity. As to the possible sources of federal and state sovereign immunity, see note 16 and sources cited therein.

${ }^{2}$ Writing for the Court, Justice Brandeis has declared, "[t]he rule that the United States may not be sued without its consent is all embracing." Lynch v United States, 292 US 571, 581 (1934).

${ }^{3}$ In the context of federal sovereign immunity, Congress has the power to tender the consent of the United States. With respect to state sovereign immunity, Congress and state legislatures share power to waive state immunity. See text at note 20 .

- The officer suit, or official capacity suit, must be distinguished from suits against officers in their personal capacity. Official capacity suits seek injunctive or declaratory relief ordering officers of the state to perform some action in their official capacity. Suits against officers in their personal capacity seek relief directly from the officer personally, usually in the form of money damages. Personal capacity suits have nothing to do with sovereign immunity since the officer, not the government, must pay any judgment. Still, some commentators have argued that, because the government in practice usually pays the judgments rendered against its officers, these suits are in fact another limitation on sovereign immunity. See Louis L. Jaffe, Suits Against Governments and Officers: Damage Actions, 77 Harv 
only through its officers, the officer suit fiction presents a powerful device by which the judiciary can check the ambit of sovereign immunity even in the absence of a legislative waiver. ${ }^{5}$

If the officer suit fiction were pursued to the extreme, sovereign immunity would degenerate into a mere pleading rule. Yet the officer suit fiction is itself limited, and sovereign immunity retains some vitality. Suits against officers in their official capacities continue to be barred by sovereign immunity if the plaintiff seeks certain forms of relief, especially a monetary award or an injunction that would lead to a monetary payment. ${ }^{6}$

In Edelman $v$ Jordan, ${ }^{7}$ the Supreme Court addressed the question of what relief could be obtained through the officer suit fiction by plaintiffs contesting denial of statutory entitlement benefits. The Court prohibited all "retroactive" relief because such relief would have a "practical effect indistinguishable . . . from an award of damages"s and because it would "resemble a money judgment payable out of the state treasury." "Nevertheless, the Court stated that "prospective" relief would be allowed even though such relief might have "an ancillary effect on the state treasury."10

Focusing on the Court's decision in Edelman, this comment examines the officer suit fiction in the context of federal statutory entitlement benefits. Section I of the comment briefly identifies the origins of sovereign immunity and the role of the officer suit fiction in entitlement litigation. Section II traces the historical origins of the limitations on the forms of relief available in an officer suit, beginning with nineteenth century cases. Section III examines the specific way in which Edelman reformulated these limitations on the officer suit fiction. This section then attempts to establish a working definition of the retroactive/prospective distinction as applied in Edelman and in lower court opinions.

Section IV examines the retroactive/prospective rule in greater

L Rev 209, 227-28 (1963).

- In Kentucky $v$ Graham, 473 US 159, 166 (1985), the Supreme Court acknowledged that "an official-capacity suit is, in all respects other than name, . . . a suit against the [government] entity." Nonetheless, the Court recognized that the officer suit fiction is a real exception to sovereign immunity, holding that "[i]n an injunctive or declaratory action grounded on federal law, the State's [sovereign] immunity can be overcome by naming state officials as defendants." Id at $169 \mathrm{n} 18$.

B See Larson, 337 US 682 (federal sovereign immunity); Edelman $v$ Jordan, 415 US 651 (1974) (state sovereign immunity).

7415 US 651 (1974).

${ }^{8}$ Id at 668 .

Id at 666 .

10 Id at 668. 
detail and concludes that the rule fails to achieve the Edelman Court's stated objectives. This section then develops a limitation on the officer suit fiction that demands an investigation into the temporal dimension of the federal statutory and constitutional rights of a plaintiff. Under this limitation, the officer suit fiction would be available to enforce current federal rights but not to provide compensation or any other remedy for past violations of rights. Finally, section V evaluates recent arguments by commentators and courts that call for a repudiation of Edelman and a return to the nineteenth century version of the officer suit fiction. Section V concludes with a brief look at how the Court has already expanded the Edelman definition of prospective relief to protect rights that the Court views as particularly important.

\section{A Brief Introduction to Sovereign ImMunity}

\section{A. General Principles of Sovereign Immunity}

The doctrine of sovereign immunity originated in early English law, which provided that no subject could sue the sovereign without his consent. ${ }^{11}$ This principle was justified in various ways, including "[t]he king can do no wrong"12 and "it would be a logical anomaly for the King to issue or enforce a writ against himself."13 Despite the absolute terms in which English sovereign immunity was stated, the doctrine had already been drastically circumscribed by the time of the American Revolution. As Professor Jaffe has shown, the King's immunity from suit was limited in two major ways: by the petition of right, whereby the King granted a perfunctory ${ }^{14}$ consent, and by suits against officers. ${ }^{15}$ Not surprisingly, the American doctrine of sovereign immunity ${ }^{16}$ has followed a similar

11 "For Blackstone, as for earlier jurists and commentators, the doctrine of sovereign immunity was simply a way of stating that the king was not amenable to the jurisdiction of his own courts unless he assented to such jurisdiction." Clyde E. Jacobs, The Eleventh Amendment and Sovereign Immunity 7 (Greenwood, 1972).

${ }_{12}$ William Blackstone, 1 Commentaries on the Laws of England *238 (Chicago, 1979).

13 Louis L. Jaffe, Suits Against Governments and Officers: Sovereign Immunity, 77 Harv L Rev 1, 3 (1963), citing Sir Frederick Pollack and Frederic W. Maitland, 1 The History of English Law 518 (Cambridge, 2d ed 1898).

${ }^{14}$ In England, the petition of right served as the means for the king to grant consent to suit "as a matter of course." Jacobs, Sovereign Immunity at 7 (cited in note 11).

15 Jaffe, 77 Harv L Rev at 3 (cited in note 4).

16 There is some doubt as to the source of sovereign immunity for both the states and the United States. The Eleventh Amendment is often cited as the source for state sovereign immunity, but the text of this Amendment is extremely narrow:

The Judicial Power of the United States shall not be construed to extend to any suit in law or equity, commenced or prosecuted against one of the United States by Citizens of 
course. Sovereign immunity is described in absolute terms, but in practice it is heavily circumscribed by statutory consents to suit (for example, the Federal Tort Claims Act ${ }^{17}$ ) and by suits against officers. Yet in both England and America, the background immunity of the sovereign remains ${ }^{18}$ and continues to be an important means of limiting the dimensions of sovereign liability. ${ }^{19}$

These general principles of sovereign immunity are applied easily in the context of suits against the United States. For a plaintiff to recover money damages from the federal treasury Congress must have waived federal immunity. Congress's power in this area seems to arise out of its plenary control over the treasury, as expressed in the Appropriations Clause. ${ }^{20}$ The second limitation on sovereign immunity, the officer suit fiction, allows the federal

another State, or by Citizens or Subjects of any Foreign State.

US Const, Amend XI. In Hans v Louisiana, 134 US 1 (1889), the Court held that the Eleventh Amendment was adopted to return the interpretation of Article III to its original understanding, which protected the immunity of the states: "[T] he cognizance of suits and actions [against the sovereign entities] ... was not contemplated by the Constitution when establishing the judicial power of the United States." Id at 15. Thus, the broad sovereign immunity of the states is based not on the Eleventh Amendment but on an implicit limitation of federal power. Monaco v Mississippi, 292 US 313, 322-23 (1934) (stating state sovereign immunity is an implicit limitation on Article III judicial power); Laurence H. Tribe, Intergovernmental Immunities in Litigation, Taxation, and Regulation: Separation of Powers Issues in Controversies About Federalism, 77 Harv L Rev 682, 697 (1976) (arguing that the presumptive immunity of the states should be inferred from the Tenth, not Eleventh, Amendment); Calvin Massey, State Sovereign Immunity and the Tenth and Eleventh Amendments, 56 U Chi L Rev 61 (1989).

Similarly, in Williams $v$ United States, 289 US 553, 572-73 (1933), and in Monaco $v$ Mississippi, 292 US 313 (1934), the Court stated that Article III should be interpreted to preclude suit against the United States, though the text gives no hint of any such immunity. Id at 321-22. The Court's interpretation is nonetheless valid; the framers believed that sovereign immunity was "one of the attributes of sovereignty" and part of the "general sense and the general practice of mankind." Federalist 81 (Hamilton), in Clinton Rossiter, ed, The Federalist Papers 481, 487 (Mentor, 1961).

1728 USC $\S \S 1346,2671-80$ (1982).

18 Under both the petition of right and the FTCA, the power to limit recovery or to withdraw consent remains. See Jacobs, Sovereign Immunity at 8 (cited in note 11), commenting that "the king might legally refuse to be impleaded;" California v Arizona, 440 US 59,65 (1979) ("It is clear, of course, that Congress could refuse to waive the Nation's sovereign immunity in all cases or only in some cases but in all courts.").

10 In 19th century England, the theory of sovereign immunity was invoked so that the petition of right would not make the Crown liable for the torts of her servants. Feather $v$ The Queen, 122 Eng Rep 1191, 1205 (QB 1865). In the United States there exist similar limitations on legislative waivers of sovereign immunity (the analogue to the petition of right). See Comment, The Discretionary Function Exception and Mandatory Regulations, 54 U Chi L Rev 1300 (1987) (discussing a particularly important statutory limitation on the United States' liability).

${ }^{20}$ US Const, Art I, $\S 9$, cl 7. See also Federalist 58 (Madison), in Federalist Papers 356, 359 (cited in note 16). 
courts $^{21}$ to issue injunctions against federal officers when they are acting in violation of federal statutory or constitutional law. The officer suit fiction is grounded in the Supremacy Clause, ${ }^{22}$ which can be viewed as a limited consent to suit consistent with the rule of law. ${ }^{23}$

State sovereign immunity presents more difficult issues. Certainly, the state legislatures have the power to waive state sovereign immunity, but it is unclear to what extent Congress may abrogate state sovereign immunity. The question of the scope of Congressional power in this area has generated a large body of case law and academic literature. ${ }^{24}$ This comment largely avoids this question by focusing only on cases in which neither Congress nor the state legislature has waived state sovereign immunity.

21 If Congress were to withdraw all jurisdiction (or at least all federal question jurisdiction) from the lower federal courts, then the state courts would have to be available to issue injunctions, even affirmative injunctions, against federal officers. The state courts would still be bound by the Supremacy Clause and would be the only forum open for the vindication of federal constitutional and statutory rights. Paul Bator, et al, Hart \& Wechsler's The Federal Courts and the Federal System 423 (This is the conclusion of Henry Hart's famous Dialogue.)

${ }^{22}$ The officer suit fiction "gives life to the Supremacy Clause." Green v Mansour, 474 US 64, 68 (1985).

${ }^{23}$ United States $v$ Lee, 106 US 196, 220-221 (1882) (quoted in text at note 49) (justifying the officer suit fiction on rule of law principles). The rule of law justification for the officer suit fiction dates back nearly as far as sovereign immunity itself. See, John Locke Two Treatises of Government, bk 2, ch XVII, $\S 206$ ("For the King's Authority being given him only by the Law, he cannot empower any one to act against the Law, or justify him, by his Commission in so doing. The Commission, or Command of any Magistrate, where he has no Authority, being as void and insignificant, as that of any private Man. . . . For 'tis not the Commission, but the Authority, that gives the Right of acting; and against the Laws there can be no Authority." (emphasis in original)).

24 Using its power under $\S 5$ of the Fourteenth Amendment, Congress may waive state immunity. Fitzpatrick v Bitzer, 427 US 445 (1976). However, there is great uncertainty about the scope of Congress's other powers. The Court first articulated a theory of "constructive consent" that effectively permitted Congress to abrogate state sovereign immunity under its Article I powers. Parden v Terminal Ry., 377 US 184 (1964). But the theory of constructive consent has now been overruled. Welch v State Dept. of Highways, $107 \mathrm{~S} \mathrm{Ct}$ 2941 (1987). The Court must now decide whether Congress may waive state immunity to suits brought by individuals when the state has tendered no consent, constructive or otherwise. United States v Union Gas Co., 832 F2d 1343 (3rd Cir 1987), cert granted sub nom, Pennsylvania v Union Gas Co., 108 S Ct 1219 (1988); see also, In re McVey Trucking, 812 F2d 311 (7th Cir), cert denied, $108 \mathrm{~S} \mathrm{Ct} 227$ (1987). This issue has generated much academic commentary arguing that Congress can waive state immunity. Tribe, $77 \mathrm{Harv} \mathrm{L}$ Rev at 69399 (cited in note 16); John E. Nowak, The Scope of Congressional Power to Create Causes of Action Against State Governments and the History of the Eleventh and Fourteenth Amendments, 75 Colum L Rev 1413, 1444-45 (1975); William A. Fletcher, A Historical Interpretation of the Eleventh Amendment: A Narrow Construction of an Affirmative Grant of Jurisdiction Rather than a Prohibition Against Jurisdiction, 35 Stan L Rev 1033 (1983); John J. Gibbons, The Eleventh Amendment and State Sovereign Immunity: A Reinterpretation, 83 Colum L Rev 1889 (1983). 
The second limitation on sovereign immunity, the officer suit fiction, is also complicated by state sovereignty. The federal courts may not enjoin a state officer when no federal interest is at stake, ${ }^{25}$ but may enjoin state officers who are acting in violation of federal statutory or constitutional law. ${ }^{26}$ Since a state officer's duties are defined by state and not federal law, there will be many situations in which a state officer will be acting unlawfully but a federal court will have no jurisdiction to enjoin her activity. Again, this comment avoids these vexing state sovereign immunity issues by limiting its focus to federal entitlements programs. In these cases, jurisdiction is premised on federal question grounds and the federal courts' power to enforce the supremacy of federal law through the officer suit fiction applies with equal force against federal and state officers.

\section{B. Sovereign Immunity in Entitlements Litigation}

Though Congress has the power to waive both federal and state sovereign immunity for federally subsidized entitlement programs, ${ }^{27}$ these waivers are construed narrowly. Moreover, some provisions of these programs can be read as express invocations of sovereign immunity. ${ }^{28}$ Thus, in many instances, sovereign immunity prevents entitlement beneficiaries from suing the government directly, and the officer suit fiction provides the only remedy for beneficiaries harmed by government illegalities.

In order to bring an officer suit in federal court, a beneficiary must first allege that an officer has acted in violation of a valid federal statute or the Constitution. ${ }^{29}$ Once this is shown, the suits

${ }^{25}$ Pennhurst State School \& Hosp. $v$ Halderman, 465 US 89 (1984) (holding that the pendent jurisdiction of federal courts may not encompass suits to enjoin state officers under state law).

${ }^{26}$ Ex parte Young, 209 US 123 (1908).

${ }^{27}$ Congress has effective power to pressure the states to waive sovereign immunity, since it can condition the receipt of federal entitlement funds on the states' waiver. See Edelman, 415 US at 673-74 (noting that Congress could impose such a condition on state participation in federal programs). Alternatively, Congress could invoke the Equal Protection Clause of the Fourteenth Amendment as the substantive provision by which it legislates entitlement benefits. Congress could then waive state sovereign immunity pursuant to its enforcement powers under $\S 5$ of the Fourteenth Amendment. Fitzpatrick v Bitzer, 427 US 445 (1976). See, generally, Frank I. Michelman, Welfare Rights in a Constitutional Democracy, 1979 Wash U L Q 659. Professor Michelman argues that such rights could be judicially created, whereas this comment only assumes that Congress may legislate such rights under its $\S 5$ powers.

${ }^{28}$ Bartlett v Bowen, 816 F2d 695, 712 (DC Cir 1987) (Bork dissenting), reh denied, Bartlett v Bowen, 824 F2d 1240 (DC Cir 1987).

${ }^{28}$ Larson, 337 US at 690-691. In determining whether a federal officer has acted in 
against the officer will still be barred by sovereign immunity if the plaintiff seeks certain forms of relief, especially a monetary award or an injunction that would lead to a monetary payment. In Edelman, the Supreme Court held that a plaintiff may sue a government officer to obtain prospective injunctive relief that compels the government to comply with federal law in all future disbursements of entitlement benefits. However, the Court expressly prohibited "retroactive" relief, which would require the government to pay benefits already due. This so-called "Edelman rule" has been applied against both federal and state officers in suits challenging an official's actions on both statutory and constitutional grounds. The remainder of this comment focuses on the Edelman rule and demonstrates that the Edelman prohibition on retroactive relief functions as an arbitrary line that truncates the federal rights of entitlement beneficiaries.

\section{The Historical Antecedents of the Edelman Rule}

While the specific rule formulated in Edelman was novel, the basic tendency of the Court to withhold certain forms of relief in officer suits was not new. In the nineteenth century, the officer suit fiction was limited by common law rights. In that era, however, such a limitation did not impede the enforcement of federal rights since those rights were largely given their content by common law

conformity with constitutional and statutory law, a court will look not just at the officer's action, but at the entire statutory scheme. Thus, even if a government administrator wrongfully denies a valid entitlement claim, the officer suit may not be available if the government has provided alternative remedial procedures that comport with due process. Larson, 337 US 682, 703 n 27 (1949); Malone v Bowdoin, 369 US 643, 647-48 (1962). Thus, within an overall statutory framework, an officer's "lawful authority" may encompass large discretion, subject to further administrative review that provides due process and compensation when mistakes do occur. See also, Jaffe, 77 Harv L Rev at 39 (cited in note 4). This expansive definition of an officer's lawful authority prevents plaintiffs from using the officer suit fiction to circumvent the proper administrative process and, hence, acts as an exhaustion requirement that protects executive flexibility. Larson, 337 US at 704. See also id at 705 (Douglas concurring) (noting that a contrary rule would "cause intolerable interference with public administration" and would "clog this governmental function with intolerable burdens.")

Nonetheless, in actions against state officials under $\S 1983$, the Court imposes no such similar exhaustion requirement. See, Patsy $v$ Board of Regents of the State of Florida, 457 US 496 (1982). But compare Parratt v Taylor, 451 US 527 (1981) (applying Larson-type reasoning to a $\$ 1983$ takings suit brought by a state prisoner); Toledo, Peoria \& W.R. Co. $v$ State of Il., 744 F2d 1296, 1299 (7th Cir 1984) (applying Larson to § 1983 action seeking an injunction to compel state officers to quiet title in plaintiff. The court denied relief since an adequate remedy existed in the state courts.) See also Knight $v$ New York, 443 F2d 415, 421 (2d Cir 1971) (refusing to allow a Takings Clause action against a state officer brought under general federal question jurisdiction where the state had provided a remedy for alleged unconstitutional action in the state courts). 
property rights. During the twentieth century, the character of individual rights against the government changed, and the federal courts vastly expanded their power to enjoin state and federal officers. Yet, even prior to Edelman, the federal courts had employed some form of balancing test, or equitable discretion, in deciding whether a requested injunction was barred by sovereign immunity. Though the character of federal rights had changed, the federal courts remained mired in the formal limits of the common law officer suit.

\section{A. Early History of the Officer Suit Fiction}

The officer suit fiction in Supreme Court jurisprudence dates at least as far back as Osborn v Bank of the United States. ${ }^{30}$ In that case, Justice Marshall stated the basic proposition of the officer suit fiction: a government officer who acts outside his authority is liable to suit. ${ }^{31}$ The defendant state officers in Osborn had levied an unconstitutional tax on the Bank of the United States. The lawful authority of the defendants to levy this tax was limited by federal supremacy over state law, thus: "[I]f the law of the State of Ohio be repugnant to the constitution, or to a law of the United States made in pursuance thereof, ... . [it can] furnish no authority to those who took, or to those who received, the money for which the suit was instituted."32 Stripped of their state authority, the defendants were little more than bank robbers who had taken money "by violence."33 Therefore, Marshall upheld an injunction requiring them to return the Bank's money. ${ }^{34}$

The fiction invoked by Marshall was more than a mere pleading rule. Once the officer had exceeded his lawful authority, he was viewed by the court completely as a private party, not as a government agent." The officer was "subject to suit only if he himself

30 22 US 738 (1824). See also United States v Peters, 9 US 115 (1809) (Court upholds admiralty jurisdiction in a suit arising out of a dispute between Pennsylvania and a citizen from another state. Though the defendants in the case were wholly private parties, they were acting as the executrixes of the former state treasurer.)

31 "[I]f the act be unconstitutional and void, it can be no justification, and both these defendants are to be considered as individuals who are amenable to the laws." Osborn, 22 US at 837 (emphasis added).

32 Id at 859.

${ }^{33}$ Id at 741 (statement of the case); see also id at 837 (referring to the taking as an "illegal act.")

${ }^{34}$ Id at 870-71.

so Id at 837 (see quote in note 33). See also Locke, Two Treatises, bk 2, ch XVII, § 206 (full quote and cite in note 23) (stating that the act of a Magistrate without authority was merely the act of a "private Man"). 
had committed an actionable wrong," ${ }^{, 36}$ and actionable wrongs were defined in reference to the common law of torts and contracts that binds all individuals, not in reference to constitutional and statutory provisions that were binding on government agents. ${ }^{37}$ Thus, the court could order the officer "to perform only his own duties and not those of the state."38

The nineteenth century version of the officer suit fiction may seem formalistic and harsh by today's standards since it limited a plaintiff's relief to cases in which a government officer was actually committing a common law tort against him. But the fiction actually served the same purpose that it serves today; it provided a means "to promote the vindication of federal rights." 39 In the nineteenth century, the rights of a plaintiff against the government were primarily negative. The Constitution was viewed as "a charter of negative rather than positive liberties," 40 and few if any statutory positive rights were created by early Congresses. ${ }^{41}$

Against this background, the nineteenth century version of the officer suit proved an effective fiction for the vindication of federal rights. If the government was interfering with personal liberty, the officer could be enjoined as a common law tortfeasor unless he could justify his actions under a constitutional state or federal statute. ${ }^{42}$ Common law rights of property also received full protection, since the common law would view officers as trespassers unless they were acting within the constitutional limits of their governmental authority. ${ }^{43}$

The full extent of officer suit's protection of private property 155.

s6 David P. Currie, Sovereign Immunity and Suits Against Officers, 1984 S Ct Rev 149,

37 "[T]he defendant officer still had to have a real interest in the controversy familiar to the common law-enough to 'justif[y] a decree against him personally.' " Michael G. Collins, The Conspiracy Theory of the Eleventh Amendment, 88 Colum L Rev 212, 223 (1988) (quoting Governor of Georgia v Madrazo, 26 US 110, 124 (1828).

${ }^{38}$ Currie, $1984 \mathrm{~S}$ Ct Rev at 163 (cited in note 36).

39 Pennhurst, 465 US at 105.

10 Jackson v City of Joliet, 715 F2d 1200, 1203 (7th Cir 1983).

11 This view corresponded to beliefs of the framers who "were not concerned that Government might do too little for the people but that it might do too much to them." Jackson, 715 F2d at 1203. Indeed, the separation of national powers was, at least in part, "intended to ensure the protection of individual rights-most prominently rights of property-against the legislature." Cass R. Sunstein, Constitutionalism After the New Deal, 101 Harv L Rev 421, 435 (1987).

12 The classic example is a suit by a prisoner against the warden under writ of habeas corpus. See United States $v$ Lee, 106 US 196, 218, 220 (1882) (drawing a parallel between the officer suit fiction and the theoretical underpinnings of habeas corpus).

13 See Meigs v McClung's Lessee, 13 US 11 (1815) (common law action of ejectment sustained against federal officers). 
is highlighted by the facts of United States $v$ Lee. ${ }^{44}$ The plaintiff, son of the late General Robert E. Lee, sued under the common law writ of ejectment to have federal officers removed from his lands. The lands were seized during the Civil War when certain federal officials misinterpreted a tax statute as requiring the actual record holder of the land to personally tender the tax. The owner of the property, at that time Mrs. Robert E. Lee, did not personally appear to tender the money. The federal officers seized the lands in the name of the United States. By the time the suit was brought, the United States had already been in possession of the land for several years and had even located a military outpost and a cemetery, Arlington National Cemetery, on the estate. ${ }^{45}$ Although the action was technically against only the officers, the United States was clearly the real party in interest.

The Court noted that sovereign immunity had been justified as a means of protecting the sovereign from "repeated suits" whereby the "means of carrying on his [the sovereign's] government in war and in peace, and the money in his treasury" would be submitted to the control of judicial tribunals. ${ }^{46}$ Nevertheless, the Court ejected the officers from the land, even though the effects on the property claimed by the government were enormous. The Court was quite candid about the reasons underlying the fiction of the officer suit, stating:

Looking at the question upon principle, and apart from the authority of adjudged cases, we think it still clearer that this branch of the defence [of sovereign immunity] cannot be maintained. It seems to be opposed to all the principles upon which the rights of the citizens, when brought in collision with the acts of the government, must be determined. In such cases

14106 US 196 (1882). For a more complete account of this politically and emotionally charged case, see Gibbons, 83 Colum L Rev at 1971-73 (cited in note 24).

15 Under the Edelman retroactive/prospective rule, the Lee lawsuit would seem to be barred, since the unlawful taking occurred in the past. Yet, the courts still allow a plaintiff who has property taken by the government to sue for the return of that property. See Spruytte v Walters, 753 F2d 498 (6th Cir 1985) (on claim by prisoner that "he is entitled to possess a tangible object [a paperback dictionary]," id at 506, the court held that injunctive relief against state prison officials seeking the return of the object was not barred by Edelman. Id at 514.). Nor does property taken have to be traditional common law property. See Demery v Kupperman, 735 F2d 1139, 1146 (9th Cir 1985) (holding that Edelman does not bar an injunction against state officer to restore plaintiff's medical license.) The continuing act of holding the plaintiff's property is seen as an ongoing violation of law. Similarly, this comment argues that the continuing act of withholding an entitlement benefit should be viewed as an ongoing violation of law. See section IV.

${ }^{4}$ Lee, 106 US at 206, quoting Briggs \& Another $v$ Light-Boats, 93 Mass 157 (1865). 
there is no safety for the citizen, except in the protection of the judicial tribunals, for rights which have been invaded by the officers of the government, professing to act in its name. ${ }^{47}$

Although the Court technically treated the suit as one against the officer personally, ${ }^{48}$ the Court explicitly recognized that this fiction was directed towards protecting "the rights of the citizens" guaranteed under the federal Constitution. The officer suit fiction was simply a necessary corollary to the rule of law principles embodied in the Supremacy Clause of the Constitution:

All the officers of government ... are creatures of the law, and are bound to obey it. It is the only supreme power in our system of government, and every man who by accepting office participates in its functions is only the more strongly bound to submit to that supremacy. ${ }^{49}$

While the officer suit fiction was tailored on one side to protect the common law property and liberty interests of individuals, on the other side it was designed to preclude suits against the sovereign for the payment of bonds, securities and other forms of public debt. The courts reasoned that an officer could not be held liable for the sovereign's contrasts and debts since, under common law agency principles, he was not a party to these obligations. ${ }^{50}$ But this limitation on the officer suit fiction was also somewhat arbitrary. If the courts had pursued the common law fiction to an extreme, the officer's participation in the creation of the obligation could have been viewed as his own action and thus he would have been liable as a party to the obligation. Still, sovereign immunity was upheld in these cases, ${ }^{51}$ not so much because the awards in these cases would have effects on the treasury, but rather because (1815).

17 Lee, 106 US at 218-19. See also, the earlier case Meigs $v$ McClung's Lessee, 13 US 11

18 Once the Court determined that the United States could not have constitutionally authorized the taking of the plaintiffs land, it then treated the suit as "a suit between two citizens [the plaintiff and the defendant officer] for the ownership of real estate." Lee, 106 US at 221 . Yet, this statement seems a mere afterthought by the Court, for nearly the entire opinion discusses the need for courts to decide "upon the rights in controversy between [citizens] and the government." Id at 220.

19 Id at 220. The holding in Lee has been limited in that the officer suit fiction is not generally available if the federal government has provided an adequate remedy to compensate the plaintiff for the taking. See Larson v Domestic \& Foreign Corp., 337 US 682 (1949); see also discussion in note 29.

${ }^{\text {so }}$ Currie, $1984 \mathrm{~S} \mathrm{Ct}$ Rev at 153 (cited in note 36). (1887).

s2 See, for example, Louisiana v Jumel, 107 US 711 (1882); In re Ayers, 123 US 443 
sovereign immunity was an implicit risk of government bonds ${ }^{82}$ and because the problem of public debt was a volatile political question..$^{53}$ Indeed, the passage of the Eleventh Amendment can be directly linked to the political backlash from the Supreme Court's decision in Chisholm $v$ Georgia ${ }^{54}$ a case that involved a state's liability for debts incurred during the course of the Revolutionary War. ${ }^{55}$ In this narrow set of cases, it makes sense to view sovereign immunity as an absolute jurisdictional bar. As a matter of necessity, the framers never intended for the courts to enforce public contracts and debts against unconsenting sovereign entities. ${ }^{56}$

\section{B. Early Twentieth Century Expansion of the Officer Suit Fiction}

In the early twentieth century, the Supreme Court was presented with a case that required a clear choice: Either adhere to the nineteenth century common law conception of the officer suit fiction, or extend the fiction to provide adequate protection for constitutionally guaranteed rights. The Court chose the latter.

Cited in Edelman as a "watershed"s7 case in sovereign immu-

${ }^{52}$ Much like bankruptcy and limited liability in corporation law, sovereign immunity was, and still is, an unavoidable risk attached to government securities. See also, Gibbons, 83 Colum L Rev at 1998 (cited in note 24) (noting that the reasoning of In re Ayers, 123 US 443 (1887), would make sovereign immunity an implied term in all public securities.) Indeed, when Alexander Hamilton recognized that sovereign immunity was a "general practice of mankind" and an exemption "now enjoyed by the government of every State in the Union," he focused on the state's "privilege of paying their own debts in their own way." Federalist 81, in Federalist Papers at 481, 487-88 (cited in note 16). Of course, this reasoning places a practical limitation on Fletcher v Peck, 10 US 87 (1810) (holding that the Contracts Clause prohibits a state from repudiating land grants), but does not overrule it since that case did not involve a promise to pay money obligation in the future.

${ }^{53}$ See Gibbons, 83 Colum L Rev at 1973-2005 (detailing the immense political pressures on the post-Reconstruction era Court not to enforce bond obligations against unconsenting-and possibly insolvent-Southern states) (cited in note 24). Indeed, the political problem of public debt pervades the history of the United States. At least one historian has suggested that the problem of enforcing public obligations provided the major political impetus for creating the federal Constitution. See Charles A. Beard, The Economic Interpretation of the Constitution of the United States 16-18, and 32-40 (Macmillan, 1944). The problem of government debt continues today, and if a state or the federal government was forced to restructure or repudiate its debt, the Supreme Court would likely resurrect the full force of sovereign immunity doctrine.

s4 2 US 419 (1793).

ss See Pennhurst, 465 US at 151 (Stevens dissenting) ("There is general agreement that the Amendment was passed because the States were fearful that federal courts would force them to pay their Revolutionary War debts, leading to their financial ruin.")

${ }^{B}$ Hamilton, for example, believed not only that the courts should not compel the states or the federal government to pay their debts, but that they could not, as a practical matter, compel payment. See, Federalist 81, in Federalist Papers at 481, 488 (cited in note 16).

${ }^{57}$ Edelman, 415 US at 664. 
nity jurisprudence, Ex parte Young ${ }^{58}$ involved the enforcement of a Minnesota statute that regulated the rates of railroads. A lower federal court found the statute unconstitutional under the Fourteenth Amendment and enjoined the state attorney general from enforcing it. When the attorney general persisted by commencing state enforcement proceedings against the non-complying railroads, the court adjudged him in contempt of the injunction. On writ of habeas corpus, the attorney general challenged the propriety of the lower court's injunction on the ground that sovereign immunity should have barred the entire suit. The sole issue before the Supreme Court was whether a federal court could properly enjoin a state officer from filing a lawsuit when that officer was acting in an official capacity and had committed no acts creating personal liability under common law.

Under the then-prevailing nineteenth century fiction, Young would have been an easy case. The state attorney general in Young had commenced state enforcement proceedings by filing suit against the railroad. Since the rate statute was unconstitutional, the lawsuit would have eventually failed. But filing a losing lawsuit against an individual was not actionable under the common law, and the Supreme Court had earlier refused to extend the officer suit fiction to a very similar case involving the threat of suit. ${ }^{59}$ The central limitation on the nineteenth century officer suit fiction was that the officer's actions were measured against common law duties, not against the more stringent standards demanded of government agents. A court could order the officer to perform those duties owed by all citizens to each other, but could not order the officer to perform any additional duties that the government might owe. ${ }^{60}$

The Young Court removed this limitation. The Court noted that it was departing from previous precedent but nonetheless held:

[I]n this case the injury complained of is the threatened commencement of suits, civil or criminal, to enforce the act, instead of ... an actual and direct trespass upon or interference with tangible property. ... The difference between an actual and direct interference with tangible property and the en-

s8 209 US 123 (1908).

s9 In re Ayers, 123 US 443 (1884). The major difference in the cases was that Ayers involved a suit over a state issued public security. See notes $52-56$ and accompanying text for a discussion of why state debt cases should be treated differently than other cases.

${ }^{60}$ Currie, $1984 \mathrm{~S}$ Ct Rev at 163 (cited in note 36). 
joining of state officers from enforcing an unconstitutional act, is not of a radical nature, and does not extend, in truth, the jurisdiction of the courts over the subject-matter. ${ }^{61}$

Although the Young Court refused to recognize the impact of its holding, the Court in fact had "effected a significant expansion of federal jurisdiction" by allowing this injunction against the state officer. ${ }^{62}$ Federal courts could now enjoin government officers to prevent them both from violating the common law ("interfer[ing] with tangible property"), and from violating the Constitution ("enforcing an unconstitutional act"). In effect, the Young Court recognized that government officers may owe duties above and beyond those demanded of ordinary citizens. ${ }^{63}$

After Young, it was unclear whether there remained any limitation on the federal courts' power to grant injunctions against government officers. Certainly, the plaintiff still had to satisfy the first requirement of the officer suit by proving that the officer was acting in violation of a federal statute or in violation of the Constitution. But once this requirement had been satisfied, could a court issue any form of injunction against a government officer, including an injunction to pay money from the sovereign treasury? Could the injunction even compel damages to be paid? Over the next sixtyfive years, the Court appeared to answer this question in the negative, but until the Edelman decision no definitive guidelines were established.

In Ford Motor Co. $v$ Dept. of the Treasury, ${ }^{64}$ the Court first indicated that some limitations still existed on the federal courts' ability to exercise equitable powers against government officers. Ford paid taxes to Indiana and later sought an injunction to compel the return of those taxes on the ground that the underlying tax statute was unconstitutional. The case was thus procedurally identical to Young: Jurisdiction was based on a federal question and the plaintiff challenged the officer's action on constitutional grounds. Still, the Court refused to reach the merits of the constitutional question because of the form of relief requested: "when the action is in essence one for the recovery of money from the

61 Young, 209 US at 167.

${ }^{62}$ Currie, $1984 \mathrm{~S}$ Ct Rev at 156 (cited in note 36).

63 The Young fiction thus created the apparent asymmetry that a federal court will treat a state officer as an agent of the state for the purpose of the Fourteenth Amendment, but not for the purpose of the Eleventh. This asymmetry can be removed if the Supremacy Clause is recognized as an express limitation on the states' sovereign immunity. See Pennhurst, 465 US at 104-05.

323 US 459 (1945). 
state, the state ... is entitled to invoke its sovereign immunity even though individual officials are nominal defendants."65

The Ford Court demarcated at least the extreme frontier of the Young rule. A plaintiff who has already voluntarily paid taxes to the state cannot use the Young rule as a "refund" mechanism to later challenge the validity of the tax. ${ }^{66}$ Yet if the plaintiff had been resisting the collection of taxes, the Young fiction would have been fully operational. ${ }^{67}$ Ford merely requires a plaintiff to assert her rights before paying over the tax, when the common law right of possession is still in her favor. Ford struck a balance between providing a fair opportunity to assert rights and allowing the finality necessary for the smooth administration of the state tax system.

After Ford the Court continued to employ the Young fiction against unconsenting states, but only in a limited manner. Though Young had departed from the common law baseline, later Courts made clear that the departure was not complete and that limitations on available relief against officers remained. Thus, in Great Northern Life Ins. Co. $v$ Read, ${ }^{68}$ the Court refused to issue an injunction that would have compelled the defendant state officer to draw money from the state treasury in accordance with a statutory duty. The Court distinguished a host of earlier precedents in which a plaintiff sued "to recover under general law possession of specific property wrongfully obtained or held" because in those cases "relief was sought under general law from wrongful acts of officials." In denying relief sought to enforce statutory duties of officers, the Court seemed to revert to the earlier nineteenth century fiction, which would remedy only the "general" or common law wrongs of officers, even though this fiction had already been substantially abandoned in Young.70

os Id at 464 .

68 The Ford Court explicitly stated that the action was only for a "refund" of taxes. 323 US at 464.

${ }^{67}$ Indeed, Young type injunctions became so frequent in state tax cases that Congress passed the Tax Injunction Act in 1937. 28 USC $§ 1341$ (1982). This statute limits the use of Young type injunctions to cases in which "a plain, speedy and effective remedy" is not available in the state courts. See Georgia R.\& B. Co. v Redwine, 342 US 299 (1952) (upholding a Young type injunction that prevented a state tax official from collecting an unconstitutional tax where no adequate state remedy was available.)

322 US 47 (1944).

69 Id at 50, 51 (emphasis added).

70 There are several reasons why the decision in Great Northern was nonetheless correct. First, the plaintiff was trying to compel the officer to conform to a state, not a federal, statutory duty. But the officer suit fiction in the federal courts does not extend to state law duties since the Supremacy Clause does not reach state law. Pennhurst, 465 US 89 . Second, 
The Court's continued hostility to departures from the "general law" became apparent in Larson v Domestic \& Foreign Commerce Corp... ${ }^{73}$ In dicta, the Court reaffirmed the principle that sovereign immunity limited the available relief even when the officer had acted beyond "lawful authority":

[A] suit may fail, as one against the sovereign, even if it is claimed that the officer being sued has acted unconstitutionally or beyond his statutory powers, if the relief requested can not be granted by merely ordering the cessation of the conduct complained of but will require affirmative action by the sovereign or the disposition of unquestionably sovereign property. ${ }^{72}$

The Larson limitation on available relief could conceivably have excluded suits over government entitlement benefits. In entitlement litigation, relief always demands affirmative action in the form of a direct payment from the sovereign treasury. As the number of government entitlement programs grew in the 1960's and 1970 's, the Larson limitation became increasingly important. However, most courts read the Larson dicta very narrowly. Adopting the view of Professor Jaffe, these courts emphasized that the suit may fail, not must fail, if the relief requires the payment of money from the sovereign treasury. ${ }^{73}$ The courts generally allowed affirmative relief unless it "would work an intolerable burden on governmental functions, outweighing any consideration of private harm." "74 Thus, prior to Edelman, the courts used their discretion to fashion remedies and took caution in granting injunctions that would require affirmative action or that would have effects on the sovereign treasury.

even though a federal question was alleged in the case, jurisdiction was based on diversity of citizenship. The Young fiction should probably not extend to diversity cases given the explicit text of the Eleventh Amendment. Finally, even if the Young fiction was extended to diversity cases, this case should have been controlled by the same reasoning as Ford since the plaintiff sought a refund of taxes voluntarily paid to the state.

${ }^{71} 337$ US 682 (1949). The primary issue in this case was the extent of executive discretion allowed federal officers in the performance of their duties. See discussion in note 29.

${ }^{72}$ Id at $691 \mathrm{n} 11$.

73 Jaffe, 77 Harv L Rev at 34 (cited in note 13).

74 State of Washington v Udall, 417 F2d 1310, 1318 (9th Cir 1969); see also Schlafly $v$ Volpe, 495 F2d 273, 277-80 (7th Cir 1974). But see Knight $v$ New York, 443 F2d 415 (2d Cir 1971) (In a suit against a state officer, Judge Friendly refused to adopt the more flexible reading of Larson offered by Professor Jaffe but carefully noted that "the plaintiff has an adequate remedy in the New York courts." Id at 421.). 


\section{The Advent of the Edelman Rule}

In Edelman, the Supreme Court held that a plaintiff may sue a government officer to obtain prospective injunctive and declaratory relief that compels the government to comply with federal law in all future disbursements of entitlement benefits. This decision redefined the landscape of permissible remedies in entitlement benefit cases and brought some practical order to the field. In Edelman, the Court drew a line between the Young principle, that a federal court could enjoin the actions of government officers, and the principle implicit in Ford and Larson, that sovereign immunity imposes some limits on this equitable power. ${ }^{75}$

However, in drawing this line, Edelman did not rely on the "affirmative action" or "unquestionably sovereign property" distinction found in Larson. Indeed, the Court recognized that permissible injunctions would often have an effect on sovereign property and the sovereign treasury, but that "[s]uch an ancillary effect ... is a permissible and often an inevitable consequence of the principle announced in Ex parte Young." ${ }^{\prime 3}$ As a later Court explained:

[T]he Court emphasized in Edelman that the distinction [between retroactive and prospective relief] did not immunize the States from their obligation to obey costly federal-court orders. The cost of compliance is "ancillary" to the prospective order enforcing federal law. ${ }^{77}$

In restructuring the law, the Edelman Court supplanted the Larson distinction in favor of a new rule and simultaneously clarified that, regardless of the cost of compliance, affirmative injunctive relief is available under Young. In a real sense, the Edelman rule expanded the power of the federal courts to issue injunctions since now the courts need not deny an injunction simply because it may have substantial effects on the government's property or treasury.

Nevertheless, the Edelman Court balked at providing a precise, rigorous test for what relief would be available under the officer suit fiction. The Court refused to draw a clear distinction between retroactive and prospective relief, noting that "the difference between the type of relief barred ... and that permitted

${ }_{76}$ "Edelman's distinction between prospective and retroactive relief fulfills the underlying purposes of Ex parte Young while at the same time preserving to an important degree the constitutional immunity of the States." See Pennhurst, 465 US at 668.

${ }^{78}$ Edelman, 415 US at 668.

77 Hutto $v$ Finney, 437 US 678, 690 (1978). 
.. . will not in many instances be that between day and night.".r8 As a result of this fundamental ambiguity, the Edelman decision has produced inconsistent and confusing case law that threatens to deprive plaintiffs of their statutory and constitutional rights.

\section{A. Edelman: Two Ways to Read "Retroactive"}

In order to understand how the retroactive/prospective distinction might be applied correctly, it is first necessary to figure out what the Court itself understood the distinction to mean. One possible interpretation of the Edelman definition of "retroactive" relief is that when issuing an injunction, a court should look for an intuitively significant event, such as the date of application for benefits, and determine retroactivity in reference to that date. Thus, a court could order relief for the beneficiaries who might apply after the injunction is issued, but it could not order any relief for all those who had applied already. An analysis of the specific facts in Edelman should help to explain this distinction.

The district court in Edelman found that the defendant state officers were administering the Illinois Aid to the Aged, Blind or Disabled ("AABD"), a joint state-federal entitlement program, in a manner contrary to federal regulations. The officers required four months to process applications, while the federal regulations mandated a time limit of approximately 45 days. ${ }^{79}$ In addition, the officers were not awarding the back benefits required by federal law to compensate for this delay. At the time the suit was commenced, the state had been following these dilatory procedures for nearly two years.

The district court's permanent injunction ordered the state officers to comply with federal law in all future processing and paying of entitlement benefits. The Supreme Court had no difficulty upholding this "prospective" part of the court's order. ${ }^{80}$ However, the district court also ordered the state officials to pay benefits that were " "wrongfully withheld to all applicants . . . who applied between July 1, 1968 [the date of the federal regulations] and April $16,197[1]$ [the date of the preliminary injunction issued by the

78 Edelman, 415 US at 667.

79 Depending on the applicant's type of disability, the regulations instituted time limits of 30,45 , or 60 days. $45 \mathrm{CFR} \S 206.10(\mathrm{a})(3)$ (1986). For later examples in the text, 45 days is used in order to simplify the problem.

so The Court noted that "prospective" injunctions are mandated by the Court's ruling in Ex parte Young. Edelman, 415 US at 664. 
District Court]." "81 The Edelman Court reversed this part of the order, holding that "a federal court's remedial power, consistent with the Eleventh Amendment, is necessarily limited to prospective injunctive relief . . . and may not include a retroactive award that requires the payment of funds from the state treasury."

An approach to defining "retroactivity" based on the application filing date is superficially appealing. This date has intuitive significance and, in any case, is easily determined during litigation. The approach seems to provide the courts with a convenient bright line rule that limits the officer suit fiction and keeps it from altogether swallowing sovereign immunity.

Under the date of application rule, it is clear that a beneficiary who applied on April 17, the day after the preliminary injunction, either would begin receiving benefits within 45 days (the federal time limit) or, if the state officers took longer than 45 days to process the application, would receive "retroactive" benefits for the amount of time that elapsed after the 45 day period had expired. This is because after April 16, the officers were under a court order to comply with federal law, which requires either processing an application on time, or paying back benefits once the application is processed. However, the plaintiff who filed on April 15, the day before the injunction, would receive no "back" benefits even if the state officers took four months to process the application. The theory behind this rule is that the state was under no "court-imposed standard to conform to a different standard"83 at the time when these earlier applications were filed. In effect, the state could continue to process applications filed before April 16 using the dilatory state procedures even though these procedures had already been enjoined as violative of federal law.

Edelman can, however, be read in a different way. The Court stressed that it was only judging "the award actually made in this case, and not one which might have been differently tailored in a different case."84 The Edelman Court might have simply been focusing on the clause in the lower court's order that awarded back benefits "to all applicants . . . who applied between July 1, 1968 [the date of the federal regulations] and April 16, 197[1] [the date

st Edelman, 415 US at 656 n 5 (quoting the district court order) (parentheticals added by the Court; emphasis added by author).

${ }^{82}$ Edelman, 415 US at 677.

ss Id at 668. This dividing line is somewhat troubling since the state was under a congressionally-imposed "obligation to conform to a different standard" even before the court order.

st Edelman, 413 US at 665. 
of the preliminary injunction issued by the District Court]." "\$s The Court might have viewed this clause as non-separable, believing that the entire clause must fail if any a portion of it was retroactive. Clearly, part of this clause was retroactive since it required the state to reimburse the plaintiffs for benefits that should have been paid all the way back to July 1, 1968 - over one year before the lawsuit was ever filed. Even the federal regulations that provide for retroactive benefits require the beneficiary to file suit within 90 days after the benefits should have been disbursed. ${ }^{86}$ Thus, the Edelman Court might have intentionally avoided drawing a clear distinction between retroactive and prospective relief. Indeed, the Court quoted language in a Second Circuit opinion suggesting that "the prompt payment of funds wrongfully withheld" will sometimes be necessary to serve federal interests. ${ }^{87}$ In couching its opinion with such cautionary language, the Edelman Court may have recognized the problems inherent in defining retroactivity based on any intuitive date such as the application filing date.

\section{B. The Inconsistent Case Law Generated by Edelman}

Despite this second possible interpretation of the Edelman opinion, the lower courts have uniformly adopted an intuitive definition of retroactivity. The courts normally look for a discrete time from which to separate retroactive from prospective relief. For example, in Medicaid benefit cases, the date selected by the courts is invariably the date on which medical services were rendered. ${ }^{88}$ This date provides a natural dividing line between the past and the present and the date is easily determined during litigation.

Unfortunately, the Medicaid cases also provide a clear example of the inconsistencies that can arise by relying on an intuitively significant date. In a Medicaid case, benefits are claimed by filing

ss Edelman, 415 US at $656 \mathrm{n} 5$ (quoting the district court order) (emphasis added).

86 45 CFR $\S 205.10$ (a)(5)(iii) (1986). Similar regulations were in force at the time of the Edelman decision.

${ }^{87}$ Edelman, 415 US at 666 n 11, quoting Rothstein $v$ Wyman, 467 F2d 226, 235 (2d Cir 1972).

${ }^{88}$ See, Florida Nursing Home Ass'n v Page, 616 F2d 1355 (5th Cir 1980), rev'd on other grounds as Florida Dept. of Health v Florida Nursing Home, 450 US 147 (1981); Wisconsin Hosp. Assn. v Reivitz, 820 F2d 863, 867 (7th Cir 1987) (After denying relief to plaintiff hospitals which were trying to collect Medicaid benefits from the state, Judge Posner noted that "[ $t]$ his case would be different if it had been brought, and a valid injunction obtained, . .. before the hospitals began to render the services subject to the April 30 statute.") (emphasis added). See also Kimble v Solomon, 599 F2d 599, 605 (4th Cir 1979); Shashoua $v$ Quern, 612 F2d 282 (7th Cir 1979) (per curiam). 
for a reimbursement. The day after an injunction is issued requiring the state to follow federal law, the state might instruct its administrators that, in the future, all applications for benefits will be divided into two groups. For claims arising out of services rendered after the injunction, the administrators would be bound to follow the appropriate federal standards. If they did not process those applications in accordance with federal law, they would be violating the "prospective" injunction and the court could impose appropriate sanctions. However, for claims arising out of services rendered before the injunction, the administrators could continue processing the claims using standards that the court had already enjoined as violative of federal law. The administrators can thus continue to violate federal law despite the injunction.

In cases involving AFDC benefits, the quest for a definite time has proved more elusive, because no one date seems particularly significant. Many courts have focused on the date that the state would have mailed the benefits (usually the first day of the statutory entitlement period). Thus, even if a plaintiff wins an injunction the very next day after the state refused to mail the check (the second day in the entitlement period), the injunction would only order the state not to withhold the next period's benefits. ${ }^{89}$ Other courts have explicitly rejected this approach and have attempted to define retroactivity based on the date the AFDC beneficiary would have spent the money. Under this approach, a court can order the state to pay a "pro rata" share of benefits proportional to the number of days that remain in the entitlement period when the injunction is issued..$^{90}$ Finally, other courts have defined retroactivity according to the last day of the entitlement period (usually the last day in the month). Using this date, a court can order a state to pay the full amount of benefits due during the current month even though the injunction is issued at the very end of the month. ${ }^{91}$

89 Coalition for Basic Human Needs v King, 654 F2d 838 (1st Cir 1981). In Massachusetts the entitlement period was two weeks. The checks were issued over a ten day period so that some recipients received their checks earlier in the two week period than others. Because of a budget lapse, the checks for the first half of the month were not mailed. The court believed that each day it delayed judgment would not "result in another day without funds but rather a third and a fourth week without funds . . . " Id at 840 .

so Buckhanon v Percy, 708 F2d 1209, 1216 (7th Cir 1983) The court did not find that the state "procedure for delivering checks is at all determinative of whether the relief ... is retroactive or prospective." Id. The court offered no reason, statutory or otherwise, why the benefits should be divided into such daily allotments.

91 Porter v Schwieker, 527 F Supp 150, 152 (D Minn 1981) (discussed in text at note 136); Turner $v$ Walsh, 435 F Supp 707, 714-15 n 9 (W D Mo 1977) (issuing an injunction on 
Remarkably, in all of these cases, the courts have devoted very little attention to the crucial question of what constitutes "retroactive" relief. Apparently, the courts all share the same premise that retroactivity can be defined by some intuitively obvious date. Yet, judging from the plethora of existing definitions, if a single date is intuitively obvious, it has so far eluded the courts.

C. "Retroactive" Relief as an Obstacle to the Enforcement of Current Federal Rights

In determining retroactivity, no court has engaged in an extensive analysis of the relevant statutory and constitutional provisions that grant substantive and procedural rights to individuals receiving benefits. Yet, these statutory and constitutional provisions specify the prospective duties that the government owes to such individuals. If retroactivity continues to be defined by reference to dates with intuitive significance (as opposed to legal significance), the "prospective" injunctions issued by the courts may not adequately protect the current federal rights of the beneficiaries.

The conflict between the Edelman bar against retroactive relief and the current federal rights of a plaintiff is highlighted by the facts of Bartlett $v$ Bowen. ${ }^{92}$ The plaintiff in Bartlett filed a claim under the Medicare Act for reimbursement of medical expenses. The plaintiff conceded that under the clear language of the statute she was not entitled to any benefits. However, she maintained that the section of the statute that prevented her from receiving benefits was unconstitutional. ${ }^{93}$ Because this challenge went to the constitutionality of the underlying statute, the agency had no authority to decide the case, so it dismissed her claim. By means of a fictional officer suit, the plaintiff appealed the agency's decision in federal district court. The Medicare Act, however, contained a jurisdiction stripping provision stating that no judicial review would be available on any claim if the amount in controversy was less than $\$ 1000$. Since the plaintiff's claim was for only $\$ 286$,

July 25 , the court noted that "the evidence indicates that welfare benefits are payable at any time within the month; thus, if ordered to do so within the month of July, defendant's action to restore benefits ... would constitute a continuation of those benefits, rather than a retroactive grant.")

82 816 F2d 695 (DC Cir 1987), reh denied, 824 F2d 1240 (DC Cir 1987).

93 The plaintiff challenged a section of the Medicare Act that contains special rules for claimants who have received care in a Christian Science nursing facility. 42 USC $\S$ $1395 \mathrm{x}(\mathrm{y})(1)$ (1982). The plaintiff contended that this section violated the Free Exercise Clause of the First Amendment and that, aside from this section, she was entitled to benefits. 
the District Court dismissed the suit for want of jurisdiction. On appeal, the D.C. Circuit reversed.

Though the majority of the Circuit panel upheld Bartlett's right to sue on purely statutory grounds ${ }^{94}$ both the majority and the dissent discussed sovereign immunity at length. In his dissenting opinion, Judge Bork read the jurisdictional limiting provision of the Medicare Act as an express invocation of sovereign immunity, ${ }^{95}$ and recent Supreme Court precedent supported his position. ${ }^{96}$ Judge Bork then argued that sovereign immunity bars suits against officers when "the relief requested can not be granted by merely ordering the cessation of the conduct complained of but will require ... the disposition of unquestionably sovereign property." "97 In Judge Bork's opinion, "a claim to governmental benefits" falls squarely within this category of officer suits and thus the plaintiff's claim should have been denied. Responding to the dissent, the majority contended that sovereign immunity could not bar the case because the plaintiff only sought a prospective injunction against a government officer, and that furthermore, sovereign immunity could not supersede a plaintiff's right to judicial review as guaranteed by the Due Process Clause.

On the facts of Bartlett, the determinative question of the sovereign immunity issue should have been whether the requested relief was "retroactive" under the Edelman rule. If it was, sover-

or The majority of the Circuit panel reasoned that, even though the language of the statute seemed to foreclose all judicial review for claims under $\$ 1000$, Congress did not intend to preclude judicial review for any claim that challenged the underlying constitutionality of the Medicare statute. Bartlett, $816 \mathrm{~F} 2 \mathrm{~d}$ at 700-01. The majority further explained that if such an exception were not read into the statute, then the limitation on jurisdiction would be unconstitutional. Id at 703, 706-07.

${ }^{25}$ Bartlett, $816 \mathrm{~F} 2 \mathrm{~d}$ at 712 (Bork dissenting).

'Bowen $v$ New York, 476 US 467, 479 (1986) (stating that a provision that provides for judicial review of entitlement benefits "is a condition on the waiver of sovereign immunity and thus must be strictly construed."). The Bowen Court employed sovereign immunity only as a canon of statutory construction. Similarly, in reviewing administrative actions, sovereign immunity is frequently used by the Court to justify restrictions on the available forum for the plaintiff's action. See also Northern Pipeline Co. $v$ Marathon Pipe Line Co., 458 US 50, 67 (1982) (Brennan, plurality opinion) (explaining the jurisdictional "public rights" doctrine in "reference to the traditional principle of sovereign immunity, which recognizes that the Government may attach conditions to its consent to be sued.") The Court's invocation of sovereign immunity as a general tool of statutory construction is unfortunate because an inference could be drawn that the government can withdraw all fora for these suits. Indeed, if the doctrine of sovereign immunity does lie behind these limitations on forum and sovereign immunity can trump a plaintiff's rights to due process, then the Court should not even review the constitutionality of administrative procedures unless Congress has expressly waived the United States' immunity.

97 Bartlett, 816 F2d at 727, quoting Larson, 337 US at 709-10. 
eign immunity would bar the court from hearing any of the plaintiff's contentions; ${ }^{98}$ if it was not, the court could then proceed to the other issues in the case-namely, the constitutionality of the jurisdiction stripping provision, and ultimately the constitutionality of the challenged section of the Medicare Act. Unfortunately, neither opinion discusses Edelman at length. The majority tried to discount the doctrine of sovereign immunity altogether, ${ }^{99}$ and in the alternative, simply asserted that the Edelman rule could not prohibit Bartlett's suit because under Edelman "[p]rospective relief is always available."100 In dissent, Judge Bork barely mentioned Edelman, ${ }^{101}$ as he preferred to rely on the older ${ }^{102}$ Larson standard for what relief would be barred by sovereign immunity.

The majority and the dissenting opinions in Bartlett illustrate the confusion that has surrounded the doctrine of sovereign immunity in the area of entitlement benefits. The debate raged for over thirty pages in the Federal Reporter but was never fully joined, as each side chose to ignore the central problem posed by Edelman. If the Edelman standard had been followed, the case would seem to have been decided incorrectly. Since the requested relief involved reimbursement for medical services that had already been rendered, the Edelman bar against "retroactive" relief (as currently interpreted by the lower courts) 103 $^{10}$ would prohibit the action. But then no forum would have ever been open to the plaintiff's constitutional challenge. If the suit were brought before the medical services were rendered, there would be no statutory jurisdiction; ${ }^{104}$ if after, it would be barred by sovereign immunity. In this case, the application of the Edelman retroactive/prospective distinction

${ }^{\text {ss }}$ Ms. Bartlett's suit could not fit within the terms of any legislative waiver of the United States' sovereign immunity. Furthermore, Judge Bork seems correct in his assessment that the jurisdiction stripping provision could be read as "expressly assert[ing] sovereign immunity as to claims under $\$ 1000$." Bartlett, 816 F2d at 712.

92 The majority derided the dissent's use of sovereign immunity in this context, calling it a "novel concept," id at 707, based on sources of authority that are "old and infrequently cited." Id at 709.

${ }^{100}$ Id at 710. The court also stated that the Edelman rule was inapplicable to federal sovereign immunity since it dealt only with the allocation of jurisdiction between the federal and state courts, rather than a true doctrine of sovereign immunity. Id. But both the Supreme Court and the lower courts have continued to cite the precedents of one doctrine of sovereign immunity when discussing the other. See, Pennhurst, 465 US at 914-17; Silva $v$ Spirito, 566 F Supp 228, 230 n 1 (D Mass 1983).

${ }^{101}$ See Bartlett, 816 F2d at 727, for Judge Bork's lone cite to Edelman.

${ }_{102}$ The Larson affirmative/negative action distinction has been supplanted by the Edelman prospective/retroactive distinction. See discussion in text at notes 75-78.

${ }^{103}$ See Medicaid cases, cited in note 88.

${ }^{104}$ Heckler $v$ Ringer, 466 US 602, 620-626 (1984). 
would effectively frustrate the plaintiff's current federal due process right. ${ }^{105}$

\section{A Current Rights Limitation on the Officer Suit Fiction}

The Edelman rule should not be read to heighten the tension between rights to statutory entitlements and sovereign immunity or between rights under the Due Process Clause and sovereign immunity. Indeed, a proper interpretation of the Edelman rule leads to a reconciliation of these apparently conflicting rights. In placing a limitation on the officer suit fiction, the Court established a baseline of rights against the government, much the way the common law established a baseline. Rights on one side of this baseline receive judicial protection from unlawful interference by government agents, while rights on the other side of this baseline are unprotected. However, the only proper way to define this baseline is by reference to the statutory entitlements granted by Congress, not by reference to some intuitive notion of "retroactivity."

To appreciate this criticism, it is necessary to investigate the underlying policy justifications advanced by the Edelman Court for the retroactive/prospective rule. In Edelman, the Court sought to limit the injunctive powers of the federal courts, and the justifications advanced by the Court to support this restriction were sound. Sovereign immunity does impose restrictions on how broadly the officer suit fiction should be interpreted. Yet, the specific rule that the Court created to restrict the officer suit fiction, the retroactive/prospective rule, is inconsistent with the Court's own articulated goals in limiting the federal court's equitable discretion. The following sections suggest that a restriction on the federal courts' power based on rights established by Congress would fulfill the expressed goals of the Edelman Court better than an ad hoc rule of retroactivity.

A. The Edelman Court's Justifications for the Retroactive/ Prospective Limitation

To rationalize the new retroactive/prospective rule, the

105 This comment does not address the fundamental constitutional issue debated in the Bartlett opinions, namely whether Congress can withdraw all jurisdiction to hear a particular federal claim from all courts. The comment argues only that sovereign immunity does not extend to cases, such as Bartlett, in which a plaintiff has a current right to due process adjudication of her entitlement benefit claim. Thus, if Congress has power to withdraw jurisdiction in cases such as Bartlett, this power must extend to a broad class of other cases that is not limited by traditional conceptions of sovereign immunity. 
Edelman Court first noted that retroactive relief might have a "practical effect indistinguishable in many aspects from an award of damages against the State." ${ }^{106}$ Like a damage award, a retroactive injunction "requires payment of state funds, not as a necessary consequence of compliance in the future with a substantive federal-question determination, but as a form of compensation to [the plaintiffs]." sured in terms of a monetary loss resulting from a past breach of a legal duty on the part of the defendant state officials." 108

In later cases, the Court has elaborated further on the reasons retroactive relief is impermissible, once again couching its explanation as a rejection of damage awards. In Green $v$ Mansour, ${ }^{100}$ the Court described the Edelman rule as barring an "injunction ordering retroactive benefits because it was effectively an award of money damages for past violations of federal law." Damages are generally granted against private parties both to compensate the victim for the loss and to deter future unlawful conduct by the defendant. ${ }^{110}$ However, the Court has held that, in suits against the government, "compensatory or deterrence interests are insufficient to overcome the dictates of [sovereign immunity]."111

In drawing this analogy to damage awards, the Court strengthened its argument against awards of retroactive entitlement benefits. The traditional core of sovereign immunity is a prohibition against imposing damage awards on the sovereign. ${ }^{112}$ In the absence of a statutory waiver, a plaintiff simply cannot receive damages from the government for violations of common law or even

${ }^{108}$ Edelman, 415 US at 668.

107 Id.

${ }^{108}$ Id.

${ }^{109} 474$ US 64, 69-70 (1985).

${ }^{110}$ See Daniel B. Dobbs, Remedies $\S 1.1$ at 2 (West, 1973). The "main purpose" of damages is compensation but " $t \mathrm{t}]$ here are elements of damages that are not entirely compensatory-punitive damages for example."

11 Green, 474 US at 68. See also Papasan v Allain, 478 US 265, 278 (1986). (Relief is not available for "cases in which that relief is intended indirectly to encourage compliance with federal law through deterrence or directly to meet third-party interests such as compensation.").

112 Nearly every court, including the Bartlett majority, has recognized the sovereign's immunity from damages. Bartlett, 816 F2d at 710. Congress has also recognized that a general waiver of federal sovereign immunity to damage awards might be an unwise policy choice. In 1976, Congress waived a large portion of the federal government's sovereign immunity, yet it explicitly limited the waiver to actions "seeking other than money damages." 5 USC $\S 702$ (1982). Furthermore, the Federal Tort Claims Act has expressly reserved the United States' sovereign immunity as to punitive damages. 28 USC § 2674 (1982) (providing that the United States "shall not be liable . . . for punitive damages."). 
constitutional rights. For example, if a person's home is invaded in violation of the Fourth Amendment, that person has no damage remedy against the government. ${ }^{113}$ Indeed, if the federal courts could employ general equitable powers to fashion damage awards against the government, the doctrine of sovereign immunity could no longer "be conceived of as having any present force."114

While Edelman expressly prohibited the imposition of damage awards against the government, the Court also specifically allowed prospective relief. Later courts have declared that prospective relief "fulfills the underlying purpose of Ex parte Young"116 which is "the need to promote the vindication of federal rights." "Bis But the Court has emphasized that the federal rights must be current and the violation ongoing in order for the Young rule to operate:

Young has been focused on cases in which a violation of federal law by a state official is ongoing as opposed to cases in which federal law has been violated at one time or over a period of time in the past. ${ }^{117}$

Given this interpretation of Young, the Edelman decision becomes a choice in how and when federal law will be enforced against government officers. The retroactive/prospective distinction of the Edelman Court defines that enforcement in two ways: First, the distinction assures that a government will not be liable for damage awards imposed by the courts in their equitable discretion. Second, it allows the vindication of current federal rights through direct injunctions against government officers. Given these two goals of the Edelman distinction, the conflict between enforcing current federal rights and preserving sovereign immunity

11 The only damage remedies that are available to such a plaintiff are against the government officers in their individual capacity. For state officers, the cause of action derives from the common law of torts or from 42 USC $\S 1983$. For federal officers, damage actions can be maintained directly under the Constitution. See Bivens $v$ Six Unknown Named Agents of Federal Bureau of Narcotics, 403 US 388 (1971). These suits are maintained against the officer in her personal capacity, and the officer, not the government, is held personally accountable for the payment of any money damage award. See also note 4 (discussing the difference between the officer suit fiction and suits against officers in their individual capacity).

${ }^{114}$ Edelman, 415 US at 665 . See also Pennhurst, 465 US at 105 ("[In Edelman], we declined to extend the fiction of Young to encompass retroactive relief, for to do so would effectively eliminate the constitutional immunity of the States.").

11 Pennhurst, 465 US at 106.

118 Id at 105. Of course, this underlying purpose pre-dates Young. Historically, the goal of the officer suit fiction has always been to enforce individual rights against unconsenting sovereigns. See discussion in text at notes $22-23$ and in section II.A.

117 Papasan, 478 US at 277-78. 
should not exist. A federal court should always have the power to enjoin ongoing violations of federal law; it should not have the power to impose damages on the public treasury as a result of an officer's past violations. Yet, as the fierce debate between the majority and dissenting opinions in Bartlett illustrates, Edelman has created tensions between current federal rights and sovereign immunity.

Why have these tensions developed? One easy answer is that the lower courts have misinterpreted the Edelman rule and that the ad hoc, intuitive approaches taken by these courts is not in accord with Edelman.118 However, the Supreme Court has discussed the Edelman rule in many later cases and it has never noted such systematic misinterpretation by the lower courts. A more troubling answer is that these tensions stem from a flaw in the Edelman Court's own implicit definition of retroactivity, a definition that contradicts the purposes behind the retroactive/prospective distinction.

B. A Critique of the Edelman Definition of Retroactivity and a Proposal for a Current Rights Approach

Once the Edelman Court determined that "retroactive" relief was impermissible, the question became what relief would be considered retroactive. In later cases, the Court has suggested that this question should be answered by reference to the current federal rights of the plaintiff, since the Young doctrine is designed to vindicate these rights through injunctions of "ongoing" violations. ${ }^{119}$ Courts should consider an entitlement right current if Congress has defined a time period for receiving the entitlement and that period has not yet expired. To determine the current federal rights of the plaintiff, a court should begin with an investigation of the relevant federal statutes.

The Edelman Court, however, failed to analyze the AABD statute to determine what specific rights it conferred on the plaintiffs. Rather, the Court advanced an argument formulated by the Second Circuit:

The second federal policy which might arguably be furthered by retroactive benefits is the fundamental goal of congressional welfare legislation-the satisfaction of the ascertained

${ }^{118}$ See earlier discussion on the two possible interpretations of the Edelman opinion in section II.A.

119 Papasan, 478 US at 277. 
needs of impoverished persons. ... [T]here may perhaps be cases in which the prompt payment of funds wrongfully withheld will serve that end. As time goes by, however, retroactive payments become compensatory rather than remedial; the coincidence between previously ascertained and existing needs becomes less clear. ${ }^{120}$

Clearly, this argument is correct as a general estimation of congressional intent, but there are two major problems with the Court using it to justify the Edelman rule. First, the argument explicitly recognizes that the prompt payment of funds might fulfill federal policy goals. If welfare benefits are wrongfully withheld and the plaintiff files suit the very next day, a court should have no difficulty ordering the state to release the benefits. The benefits may be received a few days or weeks late, but the payment will not resemble an award of damages; it will more closely resemble the ordinary monthly payment, albeit a few weeks late. The payment will most likely be used to meet the "existing needs" of the plaintiff. Yet, under the Edelman rule (or at least under the lower courts' approach to the Edelman rule), a court is likely to deny relief since the intuitive date to determine retroactivity, the date on which the state should have issued the payment, will already have passed. Indeed, on the same facts as this hypothetical, the First Circuit did deny "retroactive" relief to the plaintiff class. ${ }^{121}$

The second, more fundamental flaw in Edelman is that Congress had already determined that the Secretary of Health and Human Services should determine how much time must pass before the restoration of previously withheld benefits would no longer further federal policy. ${ }^{122}$ The Secretary had exercised this authority and had promulgated a rule allowing beneficiaries to recover wrongfully withheld benefits if they commenced an action

120 Edelman, 415 US at 666 n 11 (quoting Rothstein $v$ Wyman, 467 F2d 226, 235 (2nd Cir 1972)).

121 See Coalition for Basic Human Needs v King, 654 F2d 838 (1st Cir 1981). The only case that seems to have recognized that the Edelman rule could be interpreted flexibly was Porter $v$ Schweiker, 527 F Supp 150, 152 (D Minn 1981), wherein the court looked to the statutory intent to allow previously withheld monthly benefits to be disbursed before the end of the applicable month.

122 The statute in effect when the Edelman case arose required that each state AABD plan must provide "such methods of administration ... as are found by the Secretary to be necessary for the proper and efficient operation of the plan." 42 USC $\S 1382(a)(5)(A)(1970)$. The current statute is even more explicit, providing that "the State will comply with such other rules as the Secretary finds necessary to achieve efficient and effective administration of this subsection ... including protection of hearing rights for any individual aggrieved by action taken by the State." 42 USC $\$ 1383(\mathrm{~g})(4)(B)$ (1982). 
within 90 days after a payment was denied. ${ }^{123}$ This administrative rule can be analogized to statutes of limitations which allow even real property rights to be lost if they are not asserted in a timely fashion. Since the Edelman rule provides for the vindication of current federal rights, ${ }^{124}$ the plaintiff's rights should have been read in light of this administrative definition of the "currency" of the statutory rights, not the Court's own definition.

The Edelman Court assumed that retroactivity could be defined without reference to the statutes and regulations that govern the program. Yet, the agency's regulations already settled the exact policy question underlying the majority's concern about retroactivity. The regulations defined how much time must pass before an award of past benefits would no longer further the "fundamental goal" of the welfare legislation. Given these regulations, an injunction to pay benefits from three months prior to the filing of the lawsuit would not have been retroactive within the Edelman Court's definition. It would not be an award "measured in terms of a monetary loss resulting from a past breach of a legal duty on the part of the defendant state officials."

If the federal statute (as interpreted by the agency) ${ }^{126}$ demands that the state pay benefits accrued over the last three months, then the statute has given the beneficiaries a continuing right to receive those benefits. The statute has merely defined the temporal dimension of the right: It exists for three months. Under the Court's reasoning in Edelman and later cases, no principled

${ }^{223} 45$ CFR $\S 205.10$ (a)(5)(iii) (10-1-86) (similar regulations were in force at the time of the Edelman decision, see Edelman, 415 US at 692-93 (Marshall dissenting).) The federal courts often defer to an administrative agency's determination of Congressional intent. See Griggs $v$ Duke Power, 401 US 424, 433-434 (1971). Of course, the Edelman Court could have overruled the agency and held the statute not to grant a right to restoration of benefits, but the Court did not even discuss the statute's intent.

In his dissenting opinion, Justice Marshall did discuss these regulations and noted that they required the states to provide a fair hearing and to make corrective payments retroactively in the event of a successful challenge. Edelman, 415 US at 692-93 (Marshall dissenting). Unfortunately, Marshall erred in accepting the majority's premise that these benefits were retroactive relief and thus could not be enforced against the state unless it had waived its sovereign immunity. Marshall merely argued that, since the state had freely chosen to participate in the program, the state should be deemed to have waived its immunity. Id at 693.

124 See text at notes 115-17.

125 Edelman, 415 US at 668.

${ }^{28}$ The agency's rules must be viewed as an integral part of the statute since Congress delegated authority to that agency. See, Frank H. Easterbrook, Statutes' Domains, 50 U Chi L Rev 533, 546 (1983) (stating that a legislature can instruct agencies to design rules to achieve a legislative goal, and "[i]n that event, the subsequent selection of rules implements the actual legislative decision.") 
distinction can be drawn between the beneficiary's current right to be paid wrongfully withheld benefits for the last three months and the current right to be paid next month's benefits. While both rights have effects on the treasury of the state, both are defined by a statute (or an agency regulation) to be current rights, and both further the federal goal of providing money to meet the urgent needs of the impoverished. Under Young, a court should have the power to enjoin an ongoing violation of either of these rights. By substituting its own judgment of how long statutory benefit rights remain current in place of Congress's (or the executive agency's), the Edelman Court redefined the substantive rights of the plaintiff and usurped a legislative power.

C. Current Rights and the Sovereign's Protection Against Damage Awards

Many rights may seem intuitively retroactive-for example, the right to be paid Medicare benefits for services already rendered, or the right to be paid benefits wrongfully withheld over the past several months. Under the present interpretation of Edelman, a federal court is virtually powerless to enjoin violations of these rights. Yet, these rights must be viewed as current rights if a statute has defined the rights as current. There is no reason why Congress cannot define a right to be paid money tomorrow contingent on an event that occurred yesterday. A violation of such a right, the refusal to pay the sum presently due the beneficiary, must be seen as an ongoing violation of federal law.

In the application to suits against state officers, the current rights approach is not equivalent to allowing Congress to waive the sovereign immunity of the states. Though Congress might require the state to make a monetary payment to the plaintiff, it is not legislating a damage award against the state. Damage awards attempt to deter the state from illegal behavior and to compensate the plaintiff for the effects of this behavior. Although an injunction ordering payment of money by the state may have some deterrence or compensatory effect, the purpose of the injunction is to enforce existing legal rights, not to punish wrongful behavior. Entitlement programs are designed to transfer wealth in order to help beneficiaries meet their needs. The payment of wrongfully withheld benefits from the past few months still furthers this goal. ${ }^{127}$ 
Moreover, a state cannot avoid or change its liability for a damage award once final judgment is entered. ${ }^{128}$ In contrast, a government can avoid liability under an injunction by repealing or withdrawing from a substantive entitlement program. ${ }^{129}$ The injunction against the officers only orders them to follow federal law, not to pay money to any individuals. Thus, if the state were to withdraw from the entitlement program after the injunction was issued against the officers but before payment had been made, no money would have to be drawn from the state treasury. In issuing an injunction against an officer, the courts are merely enforcing statutory rights. Congress and the state legislature remain free to alter these rights and hence maintain complete control over the public fisc. ${ }^{130}$

\section{The Determination of Which Rights Are Current}

An investigation into the current rights of a plaintiff should involve a two step inquiry into the statutory and Constitutional rights of the plaintiff. The first prong of this test demands that the

everything to gain and nothing to lose by failing to comply with the congressional mandate that assistance be paid with reasonable promptness to all eligible individuals. 415 US at 692 (Marshall dissenting). The dissent's focus on the deterrent effect of retroactive remedies is unfortunate, since the courts have held that deterrence of future wrongs is not a sufficient justification to deny sovereign immunity. The Edelman bar on retroactive relief is more easily attacked from the standpoint of the need to enforce a plaintiff's current rights.

${ }^{128}$ For example, a damage award against a state for owning an unsafe toxic waste dump can not be avoided by an act of the state legislature. See United States v Union Gas, 832 F2d 1343 (3rd Cir 1987), cert granted as Pennsylvania v Union Gas, 108 S Ct 1219 (1988). Such a liability could only be imposed on a state through a legislative waiver of sovereign immunity either by the state legislature or, perhaps, by Congress. See text at notes 20-24.

${ }^{129}$ Fisch $v$ General Motors Corp., 169 F2d 266, 270-72 (6th Cir 1948) (holding that rights that are contingent on a statute can be revoked at any time by Congress even when the revocation of such rights is, in some sense, "retroactive."); see also Battaglia $v$ General Motors Corp., 169 F2d 254, 259 (2nd Cir 1948) ("[S]o long as the claims, if they were purely statutory, had not ripened into final judgment, regardless of whether the activities on which they were based had been performed, they were subject to whatever action Congress might take with respect to them.") The injunctions against the state officers do not constitute a "final judgment" against the state since the officer suit has no res judicata or collateral estoppel effects on the sovereign. See Lee, 106 US at 222, citing Carr v United States, 98 US 433 (1878).

${ }_{130}$ The power of the legislature to alter the law within constitutional limits is a fundamental principle of government. No legislature may bind a successive legislature through an ordinary legislative act. See Paul W. Kahn, Gramm-Rudman and the Capacity of Congress to Control the Future, 13 Hastings Const L Q 185 (1986). Obviously, Congress and the state legislatures remain bound by Constitutional provisions. However, no Constitutional provision commands that money be paid out of the treasury as an entitlement benefit. See Robert H. Bork, The Impossibility of Finding Welfare Rights in the Constitution, 1979 Wash U L Q 695 . 
court investigate the substantive nature of the statutory entitlement right, as defined by Congress, to determine whether the requested relief should be considered retroactive. The second prong, which recognizes that entitlement beneficiaries have due process rights under the Fifth and the Fourteenth Amendments, circumscribes sovereign immunity when the doctrine conflicts with constitutionally required procedural rights. These two prongs function as a single test to define retroactive relief through legal reasoning rather than intuitive guesswork.

\section{Statutory rights.}

Federal courts should carefully examine the temporal nature of a plaintiff's rights as defined by the applicable federal statute. ${ }^{131}$ If the right of a plaintiff is still "current" at the time the court issues its order, then the relief should not be considered "retroactive." Rather, the relief merely orders the cessation of a "continuing violation of federal law"132 and falls squarely within the Young exception to sovereign immunity.

Very often, the temporal dimension of the federal right will be defined expressly in the statute or in an accompanying agency regulation. For example, the Medicare Act specifically defines a 60 day time period during which the beneficiary may challenge a determination of benefits. ${ }^{133}$ Similarly, the regulations governing the Aid to Families with Dependent Children ("AFDC") and Medicaid programs provide for a "reasonable time, not to exceed 90 days" in which to challenge a benefits determination. ${ }^{134}$ If the challenge is successful, the agency is required to "promptly make corrective payments retroactively to the date the incorrect action was taken."135 These statutes and regulations define the time periods during which a benefit payment will still further the goals of federal policy. Each period is a fixed number of days (60 or 90) plus the time necessary to adjudicate the claim through a fair hearing. Thus, in a Medicare benefits case, the line between retroactive and

131 Under Pennhurst, federal courts may not grant an injunction against state officers based solely on state law. Pennhurst, 465 US at 106 . Thus, the investigation must be limited to the substantive entitlement rights granted or required by Congress.

${ }^{132}$ Green, 474 US at 68.

${ }_{133} 42$ USC $\S 1395 \mathrm{ff}(\mathrm{b})(1)$ (1982) refers to 42 USC § 405(b)(1) (1982), which states that any request for a hearing "must be filed within sixty days after notice [of an unfavorable decision by the Secretary] is received by the individual making such request."

134 45 CFR $\$ 205.10$ (a)(5)(iii) (1987) (AFDC); 42 CFR $\$ 431.221$ (c) (1987) (Medicaid).

${ }^{135} 45 \mathrm{CFR} \S 205.10(\mathrm{a})(18)$ (1987) (AFDC). See also 42 CFR $\S 431.246$ (1987) (Medicaid). 
prospective relief should be drawn 60 days prior to the date on which the action was commenced.

If the time period has not been defined by Congress or by the administrative agency, the courts should infer an appropriate time period from the goals of the program expressed by Congress. In Porter $v$ Schwieker, ${ }^{136}$ for example, the court inferred a period of one month as the time period during which the payment of benefits would further the Congressional intent. In that case, the state had implemented a new recoupment policy whereby overpayments to beneficiaries would be recovered through reduced payments in the future. Under this policy, the state withheld a portion of the plaintiff's October AFDC benefits. The plaintiff sued to have this policy enjoined as violative of federal law, and to have the withheld portion of October benefits disbursed. The court's order was issued on October 29th, but the court held that a reinstatement of October benefits was not retroactive relief under Edelman:

October AFDC grants are supposed to meet the needs of the recipient's family which arise in October. Although AFDC grants are generally paid on the first of the month, they may be paid or supplemented at any time during the month. Thus, an order requiring reinstatement of October benefits to be completed in October does not provide retroactive relief from the State's treasury contrary to . . Edelman. ${ }^{137}$

Though the court should have been more careful about defining what AFDC benefits are "supposed" to do-some legislative history should have been cited ${ }^{138}$ - the court's assumption was correct. A time period can be approximated by looking to the underlying purposes of the statutory entitlement program.

\section{Constitutionally required due process rights.}

While the first prong of the proposed test focuses on the substantive nature of the statutory right as defined by Congress, the second prong centers on the procedural component of the rights required by the Due Process Clauses of the Constitution. As mentioned above, the courts should consider an entitlement right "cur-

136527 F Supp 150 (D Minn 1981).

137 Id at 152.

138 Indeed, if the court had investigated the statutory and regulatory framework, it would not have had to guess at a time period. Retroactive benefits are available back to 90 days prior to the filing of an action. 45 CFR § 205.10(a)(5)(iii) (1987); 45 CFR § 205.10(a)(18) (1987). 
rent" if Congress has defined a time period for receiving the entitlement and that period has not yet expired. However, Congress does not have plenary power to redefine rights so as to deny individuals their constitutionally guaranteed rights to due process. A quantum of due process protection is joined to each substantive right conferred by the legislature. ${ }^{139}$ Thus, courts must also apply constitutional standards of due process when determining whether the requested relief is retroactive or prospective.

The Fifth and Fourteenth Amendments demand that there be some basic process associated with every deprivation of a right. Entitlement rights are no exception to this constitutional protection. In Goldberg $v$ Kelly, the Court held that "due process may require ... a determination of the precise nature of the governmental function involved as well as of the private interest that has been affected by governmental action."140 As in Goldberg, a state or federal government may have to provide a pre-termination hearing for certain essential entitlements such as welfare. In many other cases, due process might be satisfied with minimal procedures, perhaps even a summary determination before a lower official. Still, due process is never satisfied when there are no procedural protections whatsoever. ${ }^{141}$

Because substantive rights include these procedural protections, the rights necessarily involve a temporal dimension. Due process requires time to adjudicate if the plaintiff is to be afforded an opportunity to be heard. Even when entitlement rights are only protected by minimal proceedings, the procedural protections are an integral component of the initial bundle of rights given to the beneficiary. Thus, the underlying substantive entitlement rights cannot be considered extinguished until after the time necessary for due process adjudication has passed.

If the converse were true-if the substantive rights were extinguished before the procedures could have been completed-the en-

130 Goldberg $v$ Kelly, 397 US 254, 262 (1970).

140 Id at 263.

14 When absolutely no procedural protections have been provided with entitlement benefits, the courts have not hesitated to find a violation of due process. See White $v$ Roughton, 530 F2d 750, 753-54 (7th Cir 1976) ("In addition, due process requires that welfare assistance be administered to ensure fairness and freedom from arbitrary decision-making as to eligibility. ... [A] procedure, vesting virtually unfettered discretion in [the administrator] and his staff, is clearly violative of due process."); Baker-Chaput v Cammett, $406 \mathrm{~F}$ Supp 1134, 1140 (D NH 1976) (holding that due process considerations attach to even an application for entitlement benefits and that "the establishment of written, objective, and ascertainable standards is an elementary and intrinsic part of due process.") 
titlements would be no more than a "privilege" or a "gratuity."142 Assume that the government has conferred a right to receive a certain sum of money on a particular day, but the "right" is defined so as to expire on that day. If the beneficiary is denied payment, the Edelman version of sovereign immunity would preclude any suit since the violation of the right is past. Nor would the beneficiary have any remedy available before the deprivation, since at that time the suit would be anticipatory. Under this system, no remedy would exist either before or after the deprivation. Such an entitlement "right," devoid of all procedural protections, would much more closely resemble a "gratuity" or a "privilege," than an enforceable right. Thus, the Edelman rule would withdraw the protection of the officer suit fiction from an important class of modern individual rights and effectively overrule the Goldberg conception of entitlement rights.

Under this second prong of the current rights test, the sovereign immunity issue in Bartlett is easily decided. The plaintiff in Bartlett made a non-frivolous constitutional challenge to the underlying statute. Under the Due Process Clause, such a challenge can be decided only by an Article III court. Therefore, the plaintiff had a current federal right to adjudication of her claim at the time the court rendered its decision. Moreover, she claimed that if the court enjoined the administrator to apply the Medicare statute in a constitutional fashion, she would then have a current substantive right to benefits under the Medicare Act. Thus, the relief requested in the Bartlett case was properly viewed as prospective relief, which is not barred by sovereign immunity.

The current rights limitation on relief may not be as easy to apply as an intuitive concept of retroactivity. A rule that demands a rigorous inquiry into the nature of the plaintiff's rights is bound to be more challenging than one which, as Judge Coffin has noted, "admittedly elevates form over function." 143 Still, the rule strikes the proper balance between the government's legitimate interest in protecting the public treasury from damage awards and the recognized rights of entitlement beneficiaries. The more complicated nature of the currents rights rule is merely a predictable outgrowth of the more intricate and less intuitive rights spawned by modern governmental entitlements.

142 This characterization of entitlement rights was rejected in Goldberg, 397 US at 263.

${ }^{143}$ Kozera v Spirito, 723 F2d 1003, 1008 (1st Cir 1983). 


\section{The Continuing Development of the Officer Suit Fiction}

\section{A. A Retrospective View}

This comment has argued that the officer suit fiction was originally designed to enforce the dictates of the Supremacy Clause and to protect the rights of individuals against the government. Yet, the common law rhetoric that defined the nineteenth century officer suit continues to exert its influence. Indeed, in a recent article, Professor David Currie traces the history of the officer suit fiction and, after noting the inconsistencies in Supreme Court precedents, argues that the Court has "gone astray" from the original doctrine. ${ }^{14}$ Concluding that the Court should not "order[] officers who are suable only on the theory that they are not the state to pay money that only the state has a duty to pay,"145 Professor Currie advocates a return to the formal limitations of the nineteenth century fiction.

The Seventh Circuit has cited Professor Currie's article with favor, and, in denying relief in a suit against state officers, it has noted:

Plaintiffs sued the state officials responsible for administering the AFDC program. These officials did not commit torts or other wrongs against the plaintiffs independent of their implementation of state law. ${ }^{146}$

Though the Seventh Circuit did recognize that Young injunctions are available "to end a continuing violation of federal law," it concluded that "Young is a narrow and somewhat anomalous sidestep."147

In Bartlett, Judge Bork also advanced a form of this argument, stating:

Bartlett presents a claim that has always been treated as different in kind, one which may be barred, even as to constitu-

144 Currie, $1984 \mathrm{~S} \mathrm{Ct}$ Rev at 150 (cited in note 16).

145 Id at 168.

${ }^{146}$ Watkins $v$ Blinzinger, 789 F2d 474, 483 (7th Cir 1986). To support this view, Judge Easterbrook cited Professor Currie's article and a nineteenth century case (In re Ayers, 123 US 443 (1887)) that had been either overruled or drastically limited by Young.

167 Watkins, 789 F2d at 484 . In another Seventh Circuit opinion, Judge Posner also tried to cabin in the scope of Ex parte Young, stating that "[a] suit under Ex parte Young envisages a situation in which state officials are being told in effect to leave the plaintiff alone." Wisconsin Hosp. Ass'n v Reivitz, 820 F2d 863, 867 (7th Cir 1987). This view is consistent with Judge Posner's views in Jackson v City of Joliet, 715 F2d 1200 (7th Cir 1983) that the Constitution is primarily a document of negative liberties. See text at notes $39-41$. 
tional issues, by the doctrine of sovereign immunity. . . . Bartlett is seeking a benefit from the government, not resisting a government or private enforcement action. . . . Her claim to Medicare Part A benefits addresses neither present nor future governmental coercion against her nor governmental interference with the legal duty of a private person running in her favor. ${ }^{148}$

Though Judge Bork cited Edelman, he ultimately embraced the pre-Edelman limitation on the officer suit that had been advanced by the Court in Larson $v$ Domestic \& Foreign Commerce Corp.:149

The doctrine unanimously endorsed by the members of the Larson Court, upholding sovereign immunity in the face of a constitutional challenge by a plaintiff claiming sovereign property, describes a genus of claims within which a claim to governmental benefits such as Bartlett's is a species. ${ }^{150}$

Judge Bork's position would preclude any suit concerning statutory entitlement benefits, since these suits always involve claims on property in the possession of the sovereign. Such a restrictive, formalistic application of the common law officer suit fiction is incorrect, not merely because it is inconsistent with current Supreme Court precedent, but also because it is inconsistent with the twentieth century acceptance of new statutory rights.

\section{B. The Current View}

Given the historical context of the officer suit fiction in the nineteenth century, the Court has not "gone astray" by making modifications to the officer suit fiction in the twentieth century. The changing character of individual rights against the government has demanded parallel changes in the officer suit fiction. In Ex parte Young, the Court merely recognized that the government could not constitutionally interfere with private property by forcing individuals to make their constitutional challenges in a very inconvenient procedural posture. That Court was not concerned with the technical limits of the officer suit fiction. Once the Court determined that the state's enforcement proceeding would cause "injury [to] the company, in compelling it, at great expense, to de- 
fend legal proceedings of a complicated and unusual character,"151 it readily expanded the officer suit fiction to protect private rights against the government. ${ }^{162}$

In the second half of the twentieth century, statutory positive rights have become a major form of private "property."153 The need to provide procedural protections for this "New Property" has compelled the federal courts to expand the officer suit fiction. After Edelman, affirmative injunctive relief is available through the officer suit fiction. As a repudiation of traditional limitations on the officer suit, Edelman is entirely in accord with the spirit of prior officer suit fiction cases.

Still, though the Edelman Court refused to be bound by the strict common law limits of the officer suit (as Professor Currie would have it), ${ }^{154}$ it nonetheless refused to enforce completely the statutory baseline of rights mandated by Congress. Instead, it drew a wholly arbitrary line between those rights that it chose to enforce (the "prospective") and those that it chose not to enforce (the "retroactive"). The Edelman decision is thus caught somewhere between nineteenth century common law and twentieth century statutory law.

151 Young, 209 US at 149. Minnesota had hoped to preclude federal judicial review of the constitutionality of the rate statute by setting the fines for violation at a prohibitively high level-aggregating up to several hundred million dollars in one month. John V. Orth, The Judicial Power of the United States: The Eleventh Amendment in American History 128-29 (Oxford, 1987). Without the modern declaratory judgment action, no test case would arise since no one would risk the cost of paying the fines if the statute were upheld.

${ }^{152}$ Indeed, the Young fiction served as the procedural engine that enabled the Court to defend the economic substantive due process rights that it had created in Lochner $v$ New York, 198 US 45 (1905). See, William F. Duker, Mr. Justice Rufus W. Peckham and the Case of Ex parte Young: Lochnerizing Munn v. Ilinois, 1980 BYU L Rev 539, 556 ("Ex parte Young finally secured the refuge from state regulation."). The Young decision was, in fact, considered an extremely conservative decision throughout most of the early twentieth century. See Henry J. Friendly, Federal Jurisdiction: A General View 3 n 7 (Columbia, 1973) ("Ironically, Ex parte Young, the bete noire of liberals in the writer's law school days, has become "the fountainhead" of federal power to enforce the Civil Rights Act, 42 USC § 1983.").

${ }^{28 s}$ See Charles A. Reich, The New Property, 73 Yale L J 733, 733 (1964) (United States government has emerged "as a major source of wealth. Government is a gigantic syphon. It draws in revenue and power, and pours forth wealth: money, benefits, services, contracts, franchises, and licenses. Government has always had this function. But while in early times it was minor, today's distribution of largess is on a vast, imperial scale.").

254 Professor Currie believes that Edelman could have been decided simply on the grounds that the officers had no duty to the plaintiffs. Currie, $1984 \mathrm{~S} \mathrm{Ct}$ Rev at 159 (cited in note 36) ("It would have sufficed to say that federal law imposed the duty of payment only on the State, not on any particular official."). 


\section{A Prospective View}

The glimmerings of a truly modern version of the officer suit have already appeared in the case of Milliken $v$ Bradley. ${ }^{155}$ In that case, the plaintiff class, school children from Detroit school districts, had been "subjected to past acts of 'de jure' segregation" by the defendant school board and state. ${ }^{156}$ After seven years of litigation (including one previous trip to the Supreme Court), the lower courts had finally held for the plaintiffs and ordered a comprehensive remedial plan. The sovereign immunity issue arose because the state was ordered to fund part of a remedial education program that, the Court admitted, was "compensatory in nature."167 The plan thus seemed to fall into the core of remedial measures prohibited by Edelman.

Nevertheless, the Court attempted to distinguish Edelman on two grounds. First, it held that the order, even if compensatory, was applied only prospectively - the state was only ordered to do acts in the future. ${ }^{158}$ Yet, if an order is considered prospective merely because it applies to future behavior, then the retroactive/ prospective distinction is rendered meaningless. As Professor Currie has commented:

[T] a past wrong. If that is enough to make the order "prospective," there is no such thing as a retrospective order; nobody is ever ordered to have paid yesterday. ${ }^{159}$

The second distinction that the Court advanced was that "[i]n contrast to Edelman, ... [ [t] his case simply does not involve individual citizens' conducting a raid on the state treasury for an accrued monetary liability."160 There are two serious flaws with this reasoning. If sovereign immunity is a "right of the State governments,"161 the relevant inquiry should be whether the money will be drawn from the state treasury, not whether the money is paid directly to the plaintiffs or is merely used to compensate them indirectly. More fundamentally, the Court, in distinguishing Edelman, is openly hostile towards the entitlement benefits in-

\footnotetext{
${ }^{135} 433$ US 227 (1977).

158 Id at 269.

157 Id at 290.

158 Id at $289-90$.

${ }^{159}$ Currie, $1984 \mathrm{~S} \mathrm{Ct}$ Rev at 162 (cited in note 36 ).

160 Milliken, 433 US at $290 \mathrm{n} 22$.

181 Federalist 81 (Hamilton), in Federalist Papers at 481, 488 (cited in note 16).
} 
volved in that case, equating them to "a raid" on the state treasury. Yet, Congress and the participating states have determined that such transfer payments are not "raids," they are desirable transfers of income to beneficiaries. ${ }^{162}$

The Milliken decision cannot be easily reconciled with the present interpretations of Edelman, but it can be justified under a current rights test. Requiring remedial education is not a violation of sovereign immunity since the plaintiffs had a current federal right "to the position they would have occupied in the absence of such conduct." 163 Much like the right to entitlement benefits in Edelman, the content of this right is essentially positive: The Milliken Court chose a baseline different than the existing status quo, and under this baseline state inaction would in itself be a violation of the Equal Protection Clause. ${ }^{\mathbf{1 0 4}}$

The Milliken decision represents the Court's greatest departure from the common law officer suit fiction, for the Court disregarded the technical limits of Edelman to enforce a positive right against the state. Moreover, the factual posture of Milliken is not surprising. As in Ex parte Young, the rights at issue in Milliken were derived directly from the Fourteenth Amendment and were subject to mainly judicial enforcement. ${ }^{165}$ In both cases the Court must have viewed the plaintiff's rights as worthy of protection, and in each case it readily expanded the officer suit fiction to accomplish this end. ${ }^{166}$ In the future, the Court should apply the reason-

\footnotetext{
162 The Court's hostility to statutory entitlement programs is indicative of a larger problem that Professor Sunstein has described:

[T] The Court's failure to put benefits said to be created by the government on the same footing with benefits said to be "natural" is a clear holdover from the Lochner period. The distinction itself treats the common law as unchosen and statutory benefits as a form of "intervention"- the same choice of baseline that affected the Lochner Court. Sunstein, Lochner's Legacy, 87 Colum L Rev 873, 885 (1987)

1es Milliken, 433 US at 280.

ses
}

[T] he equal protection clause is most easily read as a self-conscious rejection of Lochner-like premises. The purpose of the clause was, at least to some degree, to break up the system of subordination of blacks; the best interpretation of the clause recognizes that the existing allocation of power among the races is both artifactual and illegitimate, and its purpose is, to a greater or lesser extent, to equalize the allocation.

Sunstein, 87 Colum L Rev at 913 (cited in note 162).

${ }^{165}$ Ex parte Young involved Fourteenth Amendment Due Process rights created pursuant to the Lochner decision. See note 152. Milliken involved Equal Protection rights spawned by Brown $v$ Board of Education.

${ }^{186}$ The lower courts seem to have recognized the unique fact pattern of Milliken and have accordingly hesitated to extend the holding to other cases unless the relief sought was very similar. Compare Reed $v$ Health and Human Services, 774 F2d 1270, 1276 (4th Cir 1985) (refusing to apply the Milliken holding in a suit over entitlement benefits), with Clark 
ing in Milliken to cases involving statutory entitlement benefits so as to offer as much protection for these congressionally created positive rights as the Milliken Court offered for judicially created positive rights. ${ }^{167}$

\section{Conclusion}

This comment has offered a comprehensive view of the officer suit fiction as a necessary judicial check on sovereign immunity. Furthermore, it has suggested a limitation on the officer suit fiction based on the current federal rights of the plaintiff. This limitation fulfills the twin goals of the Edelman Court by vindicating federal rights and by providing the states and federal government with a meaningful measure of sovereign immunity. This definition assumes, of course, that the doctrine of sovereign immunity must yield to the current federal rights of plaintiffs-an assumption that is valid not only under recent Supreme Court precedent, but also under two hundred years of precedent invoking the officer suit fiction to enforce the imperative of the Supremacy Clause.

$v$ Cohen, 794 F2d 79, 83-84 (3rd Cir 1986) (Judge Gibbons writing for the court) (requiring the state, which had deprived the plaintiff of her liberty by wrongfully institutionalizing her, to fund remedial education "necessary to undo the harmful effects of the past constitutional violations").

${ }^{107}$ Milliken could also be distinguished from Edelman since the source of the substantive baseline in Milliken was established by the Constitution itself, while in Edelman the baseline (welfare payments) was only statutory. See Pennhurst, 465 US at 102-03 (apparently hinting that the Ex parte Young doctrine applies when a state official is enforcing an unconstitutional enactment, and that the Edelman rule applies when state officials have violated federal statutory law). Such a distinction would be unwise, however, given that the Supremacy Clause envisions enforcement of both federal statutory and constitutional law. Moreover, all of the entitlements cases (including Edelman) arose under both statutory provisions and the Due Process Clause of the Fourteenth Amendment. 